\title{
The Microbial Rosetta Stone Central Agricultural Database: An Information Resource on High-Consequence Plant Pathogens
}

Sophia Kamenidou, National Institute for Microbial Forensics \& Food and Agricultural Biosecurity, Oklahoma State University, Stillwater 74078; Ravi Jain and Kumar Hari, cBio Inc., Fremont, CA 94536; James M. Robertson, Federal Bureau of Investigation, Quantico, VA 22135; and Jacqueline Fletcher, National Institute for Microbial Forensics \& Food and Agricultural Biosecurity, Oklahoma State University

\begin{abstract}
Kamenidou, S., Jain, R., Hari, K., Robertson, J. M., and Fletcher, J. 2013. The microbial rosetta stone central agricultural database: An information resource on high-consequence plant pathogens. Plant Dis. 97:1097-1102.

Microbial pathogens of humans, animals, and plants can serve as potential agents of biowarfare, bioterrorism, and biocrime. Previously, the Microbial Rosetta Stone (MRS) Central database, an easily accessible informational resource tool, was developed to assist law enforcement personnel in the event of a disease investigation by providing key information on pathogens of concern. Although the database already contained information on a few high-profile plant pathogens, the coverage was insufficient considering the large number of plant pathogens that pose a threat, not only to agricultural production but also to natural plant resources such as forests and rangelands. In this project, 100 plant pathogens of high consequence were selected for study, existing literature on these agents was reviewed, and both the sources and key pathogen information provided therein were curated in the new Agricultural Database (AgDB), an accessory to the existing MRS Central Database. Chosen for inclusion in the MRS Central AgDB were plant pathogens having significant potential for damage to U.S. agricultural and natural ecosystems. The selection process included review of several previously developed plant-pathogen threat lists and recommenda-

tions from experts within the U.S. plant biosecurity community. Pathogen information was collected by searching a number of relevant literature databases, sites on the World Wide Web, and other resources. For inclusion in the MRS, the information was curated into categories: pathogen taxonomy, nomenclature synonyms, disease symptoms and geographic distribution, plant hosts, insect vectors, detection and diagnostic methods, laboratory and field protocols, sample collection, and epidemiology. The resulting AgDB enhances the MRS Central Database by summarizing and linking key information on high-threat plant diseases and their causal agents to relevant scientific literature and internet resources. The AgDB contains critical, key information on high-consequence plant pathogens, curated in a format that is readily accessible and easily searched. The resource enhances the existing MRS Central Database and provides law enforcement, forensic, and investigative personnel with an additional tool with which to respond to microbial emergencies, particularly those affecting the agricultural and environmental sectors.
\end{abstract}

Although plant pathogens usually are introduced into a nation, a region, or a field by unintentional (natural or accidental) means, intentional (criminal or terrorist) introductions are a growing concern $(2-5,10,14,28)$. Because agricultural systems and natural plant resources are both economically valuable and vulnerable to intentional tampering by individuals, groups, or nations, they have long

Corresponding author: J. M. Robertson,

E-mail: james.robertson2@ic.fbi.gov

This is publication number 10-23 of the Laboratory Division of the Federal Bureau of Investigation (FBI).

* The $\boldsymbol{e}$-Xtra logo stands for "electronic extra" and indicates that one supplementary figure and one supplementary table are included in the online edition.

The names of commercial manufacturers are provided for information only and do not imply endorsement by the FBI or the U.S. Government. The conclusions are those of the authors and should not be taken as necessarily representing the views, either expressed or implied, of the U.S. Government.

Accepted for publication 7 February 2013.

http://dx.doi.org/10.1094/PDIS-03-12-0263-RE

This article is in the public domain and not copyrightable. It may be freely reprinted with customary crediting of the source. The American Phytopathological Society, 2013. been included in bioweapons programs as potential targets $(8,27)$. Impacts of malicious introduction of plant pathogens could include reduced product quality and availability, embargoes and quarantines, lost revenues, and a host of indirect effects on downstream nodes such as packaging, transport, value-adding industries, and rural communities $(1,4,10,15,16,22,26,28)$. Federal efforts to protect U.S. agricultural and natural ecosystems from such threats include strategies for forensic investigation of potentially criminal disease outbreaks (2).

The need for capability to trace the source of a microbe identified in a plant disease outbreak and to identify those responsible for its deployment has been recognized $(8,12,28)$. New initiatives have identified existing resources and expertise, evaluated gaps, and established priorities for research, education, and outreach (8). Forensic plant pathology is an emerging subdiscipline of microbial forensics that focuses on investigation and prosecution of criminal acts involving phytopathogenic microorganisms $(7,8,20,28)$. Communication and collaboration among government agencies, scientific communities, and international organizations are critical $(11,19,28)$ to ensure preparedness, early disease detection, and robust and appropriate responses to threats posed by plant pathogens.

Despite their need to have rapid access to specific types of reliable information on plant pathogens of concern, members of the U.S. law enforcement and security community do not always have access to public databases and Internet search functions. The Microbial Rosetta Stone (MRS) database is an intuitive and sustainable investigational tool designed for the specific needs of the mi- 
crobial forensics community $(6,7,12)$. First launched in 2003 with support from the Federal Bureau of Investigation (FBI) and the Defense Advanced Research Projects Agency (DARPA), the database originally housed epidemiological and descriptive information on pathogen names, diseases, and toxins to assist federal law enforcement personnel in threat assessments, field investigations, and molecular assay development. The Department of Homeland Security (DHS) later adopted the MRS. In response to stakeholder feedback, improved schema and architectural and user interface enhancements to the initial MRS repository resulted in the creation of what is now known as the MRS Central Database.

The original MRS Database contained information on a few high-profile plant pathogens. However, the coverage of this area was insufficient considering the large number of plant pathogens that pose a threat to agricultural production and to natural plant resources such as forests and rangelands. In the current project, the objective was to enhance the content of the MRS Central Database with information on 100 plant pathogens of high consequence. Existing literature on these agents was reviewed, and both the sources and key pathogen information provided therein were curated in a new Agricultural Database (AgDB), an accessory to the existing MRS Central Database.

\section{Materials and Methods}

Pathogen selection. One hundred plant pathogens having significant potential for damage to U.S. agricultural and natural ecosystems were targeted for inclusion in the MRS Central AgDB. The selection process included review of several previously developed plant pathogen threat lists and recommendations from experts within the U.S. plant biosecurity community. Criteria used for pathogen selection included (i) pathogens on one or more of the extant lists of high-priority plant pathogens having impact on global production, trade, and society (Table 1); (ii) pathogens highlighted in recent, relevant publications or presentations on crop biosecurity $(10,11,13)$; and (iii) pathogens supported or suggested by members of the approximately 35-member Microbial Forensics Interest Group of the American Phytopathological Society (APS) at or following its annual meeting in Portland, OR in August 2009 as well as members of the APS Emerging Diseases and Pathogens Committee.

Data collection. Pathogen and disease information was collected by searching relevant literature databases, sites on the World Wide Web, and other resources. Databases searched included Agricola (http://agricola.nal.usda.gov/), Biological Abstracts (http:// science.thomsonreuters.com/cgi-bin/jrnlst/jloptions.cgi?PC=BA), PubMed (http://www.ncbi.nlm.nih.gov/pubmed/), Web of Science (http://thomsonreuters.com/web-of-science/), and Academic Search Elite (http://www.ebscohost.com/academic/academic-search-elite/). Additional Internet searches provided links to bulletins, protocols, and governmental and university websites from which supplementary pathogen and disease information is publicly available. Searches were performed using both pathogen scientific names and disease common names, including all known synonyms or previously used names, as noted in the National Center for Biotechnology Information (NCBI), the International Committee on Taxonomy of Viruses, and the Index Fungorum for each pathogen. A list of all the retrieved citations was compiled and EndNote X3
(ThomsonReuters) was used to create uniform citation styles. From each pathogen citation list, papers having content relevant to the database were selected and downloaded for curation.

Curation. Data curation followed the guidelines of a rigorous Curation Information Management System (CIMS) developed by cBio, Inc. The CIMS consists of standard operating protocols (SOPs) for data acquisition, curation, verification, submission, and analysis. A step-by-step summation of the curation process is shown in Supplementary Table S1 and is briefly described here.

First, the determination of whether a data source should or should not be curated (i.e., "dispositioned") was frequently based on the article title alone; however, abstracts and entire publications were often examined in depth to make the determination. Records generally were maintained on how each paper was dispositioned.

Next, Microsoft Excel templates with standardized column headers were utilized to review the 60 data types curated per reference. The goal of populating these templates in the initial round of curation was to define species or subspecies relevance for each data source; capture the relevant pathogen-specific information, as described in the Results section; indicate the availability of data related to bioforensics or outbreak management; and link source referencing information. Curation and quality control (QC) steps adhered to strict SOPs regarding file-naming conventions, data formatting per template column, keyword associations, and colorcoding to flag changes made during QC steps. Curated files for each pathogen were reviewed for consistency and quality control by at least two cBio scientists other than the curator. The integration of the QC steps into the curation process is depicted in Supplementary Figure S1.

Finally, the CIMS includes a curation document version control system via Microsoft Visual SourceSafe (VSS). The VSS repository was used to maintain curation workflow structure and version control. Curated files were checked in and checked out of VSS by curators or QC checkers at each stage.

In order to ensure public accessibility of the $\mathrm{AgDB}$ and allow retrieval of the data for the 100 high-consequence plant pathogens, all curation files have been made freely available for download from www.microbialrosettastone.com and www.mrscentral.com websites as a ZIP archive of Excel files. Standard desktop indexing and search tools pointed to the downloaded "Agriculture" folder of Excel files will allow querying the contents of these curation files.

\section{Results}

One hundred plant pathogens of high priority to the United States were chosen, based on the criteria indicated above and with plant pathology community input, for inclusion in the MRS Central AgDB. Pathogen and disease names, known geographic distributions, host plants, and citation sources for these agents are shown in Table 2. The listed microbes included 65 fungi and oomycetes, 18 bacteria and phytoplasmas, 12 viruses, and 5 nematodes, and these pathogens are associated with diseases of 50 agricultural commodities, 19 fruit and nut trees, 17 forest trees, and 14 horticultural commodities.

Multi-database Internet searches for the selected pathogens resulted in the retrieval of more than 8,500 published items (peerreviewed and other scientific papers, websites, bulletins, and protocols). All of these items were fully referenced in the database.

Table 1. Plant pathogen threat lists

\begin{tabular}{|c|c|}
\hline Organization $^{\mathrm{a}}$ & Lists $^{b}$ \\
\hline A. USDA Animal and Plant Health Inspection Service & Plant Pathogen Select Agent List \\
\hline B. USDA Animal and Plant Health Inspection Service & Regulated Plant Pathogens \\
\hline C. USDA National Plant Disease Recovery System & National Plant Disease Recovery System Plans \\
\hline D. USDA National Plant Disease Recovery System & National Plant Disease Recovery Fact Sheets \\
\hline E. American Phytopathological Society (APS) & Emerging Diseases \& Pathogens Committee List \\
\hline F. Council for Agricultural Science \& Technology (CAST) & List of Invasive Pests \\
\hline G. European Plant Protection Organization (EPPO) & Lists of Critical Plant Pathogens (A1 and A2) \\
\hline
\end{tabular}


Keyword curation was provided for approximately one-eighth of the articles, using the following guidelines. The highest priority was given to papers having strain-level, signature-specific data, and results on named isolates. The second priority was given to papers having named isolates and isolate background information with species-level or subspecies-level identification and description, or with no experimental data and results. Not curated papers included those with no named isolates and foreign language articles or reviews. Other considerations were level of coverage of all 100 pathogens as well as subject matter relevance, rigor, and relatively recent publication dates. Categories for curation included taxonomy, pathogen name and synonyms, disease name or names and symptoms, detection and diagnostic methods, laboratory and field protocols, sample collection guidelines, disease geographic range and distribution, plant host range, insect vectors, epidemiology, and other features of relevance.

The AgDB collection of keyword tables and descriptive data are formatted in Microsoft Excel files, with one Excel file per plant pathogen. Each file contains a list of articles and other sources from the scientific literature, deemed most relevant for the plant pathogen of interest. All articles in the pathogen literature lists are linked to external database accessions or URLs, providing users a rapid mechanism to download the original articles. The list of Excel files can be searched and downloaded by organism name.

The AgDB is the newest of several expert-curated lists of relevant literature on various biothreat agents available to users of the MRS Central Database. It was incorporated into the existing MRS Central Database, a Web-based portal providing select U.S. government users secure, password-protected access to MRS data housed in a MySQL database and maintained on a SQL server, while also allowing secure access to a user's proprietary data. As part of the MRS Central Database, the AgDB is hosted on a standard Microsoft platform developed with industry-leading .NET technologies and implemented Service-Oriented Architecture techniques, allowing for complex data to be utilized via standard interfaces. The client-side interface communicates to the database via Web services behind a secure firewall. The AgDB has been made publicly accessible from the website www.microbialrosetta stone.com and the cBio-curated data for DHS is freely available by login with username/password combination guest/guest from the website www.mrscentral.com.

\section{Discussion}

Plant resources, including crops, forests, rangelands, and natural ecosystems, are critical elements supporting our nation's security and stability. In the past decade, efforts to protect and preserve critical infrastructures from the activities of individuals and groups wishing to create harm have increased in number and become more focused (11). Although opinions vary with respect to the risk that plant pathogens might be used as biological weapons $(21,29)$, the need for more reliable and accessible information on agents of concern to plant biosecurity is well documented $(17,25)$. Several Internet sites, including those of the United States Department of Agriculture's National Plant Diagnostic Network (http://www. npdn.org/), National Plant Disease Recovery System (http://www. ars.usda.gov/research/docs.htm?docid=14271), and Animal and Plant Health Inspection Service (http://www.aphis.usda.gov/), are examples of balanced, informative sources (19). Recently, the Web-based Phytophthora Database was developed to provide a global, searchable source of information on Phytophthora spp. that can be used for enhanced outbreak management by the international community of plant pathologists (20). Similarly, emergency responders from the law enforcement community sought a comprehensive database from which key information on highthreat plant pathogens could be retrieved quickly and securely.

The MRS was designed originally as an open access database containing information on important human, animal, and plant pathogens that could be used as agents of bioterror, biowarfare, or biocrime $(6,7)$. However, as the applications of the database gradually became focused on the information needs of the law enforce- ment, forensic, and intelligence communities, the database was divided into two domains, one publicly accessible (http://www. microbialrosettastone.com) (12) and the other, now known as the MRS Central Database (http://mrscentral.com/), designated as proprietary for government use. The new AgDB enhances the MRS Central Database by summarizing and linking key information on high-threat plant diseases and their causal agents to relevant scientific literature and internet resources.

The limitation of the AgDB to just 100 plant pathogens (for budgetary reasons) proved quite challenging because it represents only a small proportion of plant-pathogenic microbes of global concern. Lists of potential threatening organisms have been developed, for various purposes, by various agencies and entities in several nations, including the United States, the European Union, Australia, and New Zealand (10,11). Each of these extant lists was prepared for a unique application. Some lists were used to prioritize research fund allocations, others for the development of safe pathogen handling protocols, and a few for preparation of response and mitigation plans. Because agencies developed prioritization criteria to meet their specific objectives, the criteria were not standardized or even compared for similarities among lists. Not surprisingly, a number of the pathogens are found on multiple lists (4).

In the current project, the plant pathogens were selected from a number of sources. including recent literature and events in addition to the existing lists. Many of them are deemed to be among the most threatening to U.S. crop systems. A "threatening pathogen" has been defined as one not present or having limited distribution in a specific geographic region (9). These pathogens are also termed introduced, non-indigenous, non-native, exotic, alien, invasive, or emerging $(9,13)$. However, a number of threatening endemic plant pathogens have been included that, if implicated in criminal events, would be of critical interest to investigators.

Our selections were influenced also by input received from working groups in phytopathology representing a broad scientific and professional community having expertise and involvement in agricultural biosecurity. We chose, primarily, plant pathogens nonindigenous to U.S. agricultural and natural ecosystems, because introduction of non-native organisms could have vast economic costs (production, trade, and eradication) and unpredictable ecological effects (13).

Despite attempts to develop science-based risk assessment methods $(14,23)$, there is a lack of consensus on the best strategies for measuring risk and threat levels for plant pathogens (24). Difficulties arise in the high levels of complexity and unpredictability with respect to the evolution, reproduction patterns, and dispersal methods of both indigenous and non-native plant pathogens, should they be introduced to the United States. For this reason, we did not rank the threat levels of the 100 high-priority plant pathogens in this curation.

One of the features that distinguish the MRS Central AgDB from other plant pathogen information databases is the identification of taxonomic and identification ambiguities in the existing literature and the creation of an "equivalent pathogens" category for cases in which multiple taxonomic designations are possible (12). Accordingly, we provided not only the most recent taxonomic classifications during curation but also all previously used classifications and nomenclatural synonyms. Although the NCBI is not an authoritative source for taxonomy and nomenclature, it is one of the most widely used. Therefore, following MRS Central precedent, taxonomy information retrieved from the NCBI Taxonomy Browser (http://www.ncbi.nih.gov/) was always included in the database but it was supplemented by any other available taxonomic classifications or synonyms.

Because the MRS Central AgDB was created to support microbial forensic investigations, the credibility of the curated information on high-priority plant pathogens is critical. For this reason, all of the keyword curation is linked back to the original, published scientific literature from which the information was retrieved. The high variability in the number of articles and the range of coverage of relevant literature available for each of the selected pathogens 
Table 2. One hundred high-consequence plant pathogens included in the Microbial Rosetta Stone Central Agricultural Database

\begin{tabular}{|c|c|c|c|c|}
\hline Pathogen & Disease name & Geographic distribution & Hosts & Citation sources $^{\mathbf{a}}$ \\
\hline \multicolumn{5}{|l|}{ Fungi and oomycetes } \\
\hline Aspergillus flavus & Aflatoxin & Worldwide & Stored grains & 27 \\
\hline Alternaria triticina & Leaf blight of wheat & India, Argentina & Wheat & $\mathrm{BNZ}$ \\
\hline Angiosorus solani & Potato smut & Chile, Peru & Potato & 11 \\
\hline Armillaria spp. & Root and heart rots of trees & North America, Europe, Africa & Ornamental and forest trees & CAST \\
\hline Bipolaris oryzae & Brown spot of rice & Asia, Africa, North America & Rice & PaDIL, Australia \\
\hline Ceratocystis autographa & Root rots of conifers & Europe & Conifers & CAST \\
\hline Cercospora zeae-maydis & Gray leaf spot of corn & North America, Africa & Corn & NIMFFAB \\
\hline Chrysomyxa spp. & Chrysomyxa rust & Canada, Northern Europe & Rhododendron; conifers & A1; $18 ;$ CAST \\
\hline Colletotrichum zeae & Anthracnose & Worldwide & Corn & $18 ;$ CAST \\
\hline \multicolumn{5}{|l|}{ Cronartium flaccidum; } \\
\hline Peridermium pini & Scots pine blister rust & Europe & Pine & NPDRS-RP \\
\hline Cronartium himalayense & Pine rust & India, Nepal & Pines & A1; 18; CAST \\
\hline Diaporthe helianthi & Phomopsis stem canker & Europe, United States (Texas) & Sunflower & EPPO \\
\hline Elsinoe australis & Sweet orange scab & Oceania, North and South America & Citrus spp. & EPPO \\
\hline Endocronartium harknessii & Western gall rust & North America & Pine & $\mathrm{A} 1 ; 11$ \\
\hline Eutypa lata & Grapevine dieback & Europe, North America, Australia & Grapevine & A1 \\
\hline Fusarium graminearum & Fusarium stem blight of wheat & Worldwide & Wheat & NIMFFAB \\
\hline Fusarium oxysporum & & North and South America; Australia, & & \\
\hline f. sp. vasinfectum & Fusarium wilt & Asia; Africa & Cotton & APS \\
\hline Ganoderma spp. & Root and wood rots of trees & Asia & Forest trees & CAST \\
\hline Geosmithia morbida & $\begin{array}{l}\text { Thousand canker disease of } \\
\text { walnut }\end{array}$ & Worldwide & Walnut & NPDRS-FS \\
\hline Guignardia citricarpa & Black spot of citrus & $\begin{array}{l}\text { Asia, Africa, South America, } \\
\text { Australia }\end{array}$ & Citrus spp. & APS, A1 \\
\hline Gymnosporangium yamadae & Japanese apple rust & Asia & Apple and related pome fruit & A1 \\
\hline Harpophora maydis & Late wilt of corn & Egypt, Hungary, India & Corn & NPDRS-RP \\
\hline Helicobasidium mompa & Wood rot of fruit trees & Japan & $\begin{array}{l}\text { Herbaceous plants and fruit } \\
\text { trees }\end{array}$ & 18; CAST \\
\hline Heterobasidion spp. & Root, butt, heart rots of trees & $\begin{array}{l}\text { Europe, Australia, Asia, } \\
\text { North America }\end{array}$ & Forest trees & CAST \\
\hline Lachnellula willcommi & Larch canker & Canada & Larch & CAST \\
\hline Lophodermella sulcigena & Needle cast of pines & Northern Europe & Pine & CAST \\
\hline Melampsora pinitorqua & Twist rust of pines & Europe & Pine & $18 ; \mathrm{CAST}$ \\
\hline Mycosphaerella gibsonii & Brown needle blight of pine & $\begin{array}{l}\text { Asia, Africa, Caribbean, } \\
\text { Central America }\end{array}$ & Pine & NPDRS-FS, A1 \\
\hline Nectria galligena & $\begin{array}{l}\text { European canker of apple and } \\
\text { pear }\end{array}$ & Europe, Chile & Apple, pear & EPPO \\
\hline Ophiostoma spp. & Wilt and wood rot of trees & Asia, Europe, North America & Forest trees & A1; CAST \\
\hline Peronosclerospora maydis & Java downy & Asia, Australia & Corn & CAST \\
\hline Peronosclerospora & & & & \\
\hline philippinensis & Philippine downy mildew & Asia, Africa & Corn & USDA SA; CAST \\
\hline Peronosclerospora sacchari & Downy mildew of sugarcane & Asia, Oceania & Sugarcane & USDA SA; CAST \\
\hline Peronospora hyosciami & & & & \\
\hline f. sp. tabacina & Blue mold of tobacco & North America & Tobacco & 27 \\
\hline Phaeoramularia spp. & Citrus fruit and leaf spot & Africa & Citrus spp. & A1 \\
\hline Phakopsora pachyrhizi & Asian soybean rust & Africa, Asia, Australia, America & Soybean & $\begin{array}{l}\text { USDA RP; } 18 ; \\
\text { CAST }\end{array}$ \\
\hline Phellinus weirii & Laminated root rot of conifers & North America, Siberia & Conifers & A1; CAST \\
\hline Phoma exigua var. foveata & Potato gangrene & Europe, Australia & Potato & EPPO \\
\hline Phoma glycinicola & Red leaf blotch & Africa & Soybean & USDA SA \\
\hline Phoma tracheiphila & Mal secco of citrus & Europe, Asia, Africa & Lemon trees; Citrus spp. & NPDRS-FS \\
\hline Phomopsis viticola & Grape phomopsis & Europe, Australia, North America & Grapevines & EPPO \\
\hline Physopella zeae & Tropical rust & $\begin{array}{l}\text { Central and South America, } \\
\text { Caribbean }\end{array}$ & Corn & 18 \\
\hline Phytophthora alni & $\begin{array}{l}\text { Root and collar rots of Alnus } \\
\text { spp. }\end{array}$ & Europe & Alder trees & NPDRS-FS \\
\hline Phytophthora cambivora & Ink disease & Europe, United States (Oregon) & $\begin{array}{l}\text { Chestnut and other forest } \\
\text { trees }\end{array}$ & CAST \\
\hline Phytophthora infestans & Late blight & Worldwide & Potato, tomato & USDA RP \\
\hline Phytophthora kernoviae & Bleeding cankers & United Kingdom, New Zealand & Forest and ornamental trees & NPDRS-RP \\
\hline Phytophthora pinifolia & Foliage blight of P. radiata & Chile & Pine & NPDRS-FS \\
\hline Phytophthora ramorum & $\begin{array}{l}\text { Sudden oak death, ramorum } \\
\text { blight }\end{array}$ & North America; Europe & $\begin{array}{l}\text { Forest and woody } \\
\text { ornamentals }\end{array}$ & EPPO \\
\hline Pleospora papaveracea & $\begin{array}{l}\text { Opium poppy mycoherbicidal } \\
\text { fungus }\end{array}$ & Worldwide & Opium poppy & 27 \\
\hline Puccinia graminis f. sp. tritici & Wheat stem rust & Worldwide & Wheat, barley & $\begin{array}{l}\text { USDA RP; } 27 \\
\text { ntinued on next page }\end{array}$ \\
\hline
\end{tabular}

a Abbreviations, in alphabetical order: A1 = EPPO A1 List; A2 = EPPO A2 List; APS = American Phytopathological Society; BNZ = Biosecurity New Zealand; CAST = Council for Agricultural Science \& Technology; EPPO = European Plant Protection Organization; NIMFFAB = National Institute of Microbial Forensics \& Food and Agricultural Biosecurity, NPDRS-FS = National Plant Disease Recovery System, Fact Sheets; NPDRS-RP = National Plant Disease Recovery System, Recovery Plans; PaDIL = Pest and Disease Image Library, Australia; USDA FS = United States Department of Agriculture Forest Service; USDA RP = USDA Animal \& Plant Health Inspection Service (APHIS) Regulated Pathogens; USDA SA = USDA-APHIS Select Agents. Cite numbers indicate authors in Literature Cited. 
Table 2. (continued from preceding page)

\begin{tabular}{|c|c|c|c|c|}
\hline Pathogen & Disease name & Geographic distribution & Hosts & Citation sources $^{\mathrm{a}}$ \\
\hline Puccinia kuehnii & Orange rust of sugarcane & $\begin{array}{l}\text { Asia, Australia, South Africa, North } \\
\text { and South America, Australia }\end{array}$ & Sugarcane & USDA RP \\
\hline Puccinia melanocephala & Sugarcane rust & $\begin{array}{l}\text { North America, South America, } \\
\text { Africa }\end{array}$ & Sugarcane & 27 \\
\hline Puccinia striiformis & Wheat stripe rust & Worldwide & Wheat & USDA RP \\
\hline Puccinia triticina & Wheat rust & Worldwide & Wheat & NPDRS-RP \\
\hline \multicolumn{5}{|l|}{ Pyricularia (=Magnaporthe) } \\
\hline grisea $(P$. oryzae $)$ & Rice blast & Worldwide & Rice & USDA RP \\
\hline Pythium volutum & Pythium root dysfunction & North America & Creeping bentgrass & 18 \\
\hline Raffaelea lauricola & Laurel wilt & North America & Red bay, avocado & USDA FS \\
\hline $\begin{array}{l}\text { Sclerophthora rayssiae var. } \\
\text { zeae }\end{array}$ & Brown stripe downy mildew & Asia & (x) & USDA SA \\
\hline Synchytrium dolichi & Gall on Fabiaceae & Africa, Asia & Soybean, cowpea & 18 \\
\hline Synchytrium endobioticum & Potato wart & Worldwide & Potato & USDA SA, A2 \\
\hline Tilletia contraversa & Dwarf bunt of wheat & Worldwide & Wheat & 11 \\
\hline Tilletia indica & Karnal bunt of wheat & $\begin{array}{l}\text { Asia, North and South America } \\
\text { (Brazil) }\end{array}$ & Wheat & APS, A1 \\
\hline Tilletia laevis & Stinking bunt of wheat & Worldwide & Wheat & 27 \\
\hline Uromyces striatus & Alfalfa rust & North America & Alfalfa & Other \\
\hline Uromyces transversalis & Gladiolus rust & $\begin{array}{l}\text { Africa, Europe, South America, } \\
\text { Oceania }\end{array}$ & Gladiolus & USDA RP \\
\hline \multicolumn{5}{|l|}{ Bacteria and phytoplasmas } \\
\hline $\begin{array}{l}\text { Acidovorax avenae subsp. } \\
\text { avenae }\end{array}$ & Bacterial brown stripe & Worldwide & Grasses & APS \\
\hline $\begin{array}{l}\text { Acidovorax avenae subsp. } \\
\text { citrulli }\end{array}$ & Bacterial fruit blotch & North America, Australia, Asia & $\begin{array}{l}\text { Cucurbits (melons, } \\
\text { pumpkins, squash) }\end{array}$ & 11 \\
\hline Candidatus Liberobacter spp. & Citrus greening disease & Asia, Africa, America & Citrus spp. & USDA RP, A1 \\
\hline 'Ca. Phlomobacter fragariae' & Strawberry marginal chlorosis & Europe, Japan & Strawberry & APS \\
\hline 'Ca. Phytoplasma mali' & Apple proliferation & Europe & Apple & APS; A2 \\
\hline $\begin{array}{l}\text { Coconut lethal yellowing } \\
\text { phytoplasma } \\
\text { Corynebacterium tritici } \\
\text { (C. rathayi) }\end{array}$ & Coconut lethal yellowing & Africa; America; Caribbean & $\begin{array}{l}\text { Coconut and other palms } \\
\text { Annual ryegrass } \\
\text { (livestock toxicity) }\end{array}$ & 18; CAST \\
\hline Flavescence doree & Phytoplasma of grape & Europe & Grapevines & A2; CAST \\
\hline $\begin{array}{l}\text { Liberobacter solanacearum; } \\
\text { L. psyllaurous }\end{array}$ & Zebra chip & North America; New Zealand & Potato & NPDRS-FS \\
\hline $\begin{array}{l}\text { Ralstonia solanacearum, } \\
\text { race } 3 \text {, biovar } 2\end{array}$ & Wilt of potato & Worldwide & Potato, tomato & USDA SA, A2 \\
\hline Rathayibacter toxicus & Gumming disease & South Africa, Oceania & Grasses & USDA SA \\
\hline $\begin{array}{l}\text { Xanthomonas axonopodis } \\
\text { pv. citri }\end{array}$ & Citrus canker & Asia, North and South America & Citrus spp. & A1; CAST \\
\hline $\begin{array}{l}X . \text { axonopodis pv. vasculorum } \\
X . \text { malvacearum }\end{array}$ & Gumming disease & Africa, South America & Sugarcane & CAST \\
\hline malvacearum & Cotton bacterial blight & Worldwide & Cotton & NIMFFAB \\
\hline X. oryzae pv. oryzae & Rice leaf blight & Worldwide & Rice & USDA SA, A1 \\
\hline X. oryzae pv. oryzicola & Rice leaf streak & Worldwide & Rice & USDA SA, A1 \\
\hline Xyllela fastidiosa & Citrus variegated chlorosis & South America & Citrus spp. & USDA SA, A1 \\
\hline Xylophilus ampelinus & Grapevine canker & Europe & Grapevine & APS, A2; CAST \\
\hline \multicolumn{5}{|l|}{ Viruses } \\
\hline Begomoviruses of cassava & Begomoviruses of cassava & Africa; India & Cassava & NIMFFAB \\
\hline Begomoviruses of tomato & Begomoviruses of tomato & Central and South America; Asia & Tomato, potato & NIMFFAB \\
\hline Citrus leprosis virus & Citrus leprosis & North and South America & Citrus spp. & A1 \\
\hline Citrus ringspot virus & Citrus ringspot virus & $\begin{array}{l}\text { Europe, Asia, Africa, North and } \\
\text { South America }\end{array}$ & Citrus spp. & CAST \\
\hline Citrus tristeza virus & Citrus tristeza & Worldwide & Citrus spp. & APS, A2 \\
\hline Indian citrus ringspot virus & Indian citrus ringspot & India & Citrus spp. & CAST \\
\hline Maize streak virus & Maize streak virus & Africa & Corn & 18 \\
\hline Pepino mosaic virus & Pepino mosaic & North and South America, Europe & Tomato & ЕPРO \\
\hline Plum pox potyvirus & Plum pox virus & $\begin{array}{l}\text { Europe, Middle East, North and } \\
\text { South America }\end{array}$ & $\begin{array}{l}\text { Stone fruit (plums, peaches, } \\
\text { cherries) }\end{array}$ & NPDRS-RP, A2 \\
\hline Soybean dwarf virus & Soybean dwarf virus & Asia, Europe, North America & Bean, soybean & APS \\
\hline Soybean stunt virus & Soybean stunt virus & Asia, North America & Soybean & CAST \\
\hline Tomato yellow leaf curl virus & Tomato yellow leaf curl & Worldwide & Tomato & $\begin{array}{l}\text { U. Melcher, personal } \\
\text { communication; A2 }\end{array}$ \\
\hline \multicolumn{5}{|l|}{ Nematodes } \\
\hline Anguina tritici & Wheat stem nematode & Worldwide & Wheat & APS \\
\hline Globodera rostochiensis & Potato golden cyst nematode & Worldwide & Potato & APS, A2 \\
\hline Heterodera latipons & $\begin{array}{l}\text { Mediterranean cereal cyst } \\
\text { nematode }\end{array}$ & Europe, Africa, Asia & Cereal grasses & 18 \\
\hline Heterodera zeae & Corn cyst nematode & India; Europe; North America & Corn & APS; 18 \\
\hline Meloidogyne spp. & Root knot nematodes & Worldwide & $\begin{array}{l}\text { Wide host range } \\
(>2.000 \text { plant species })\end{array}$ & A2 \\
\hline
\end{tabular}


was one of the major challenges during the curation process. The paucity of information on some of the agents is evidence of the need for new research and enhanced global communication on plant pathogens of concern.

The MRS Central AgDB will benefit from ongoing system support that will include continued development of effective user interfaces for multiple analysis tasks and the establishment of a committed group of data collectors and curators. Further enhancement of the database can be achieved by adding additional plant pathogens, by performing in-depth curation on a subset of the currently included plant pathogens for which a vast amount of information is available, and by regularly updating the basic curated information on the 100 pathogens of this study. The addition of a real-time, geographic mapping function is also being considered as a tool for demonstrating the distribution of outbreak strains. The developer of the AgDB, cBio Corporation, actively seeks collaborators with academic laboratories and other national and international organizations to augment the data compilations.

In summary, credible and thorough information resources on plant pathogens are needed to enhance governmental capability to minimize threats to agricultural and natural resources and to respond appropriately to plant pathogen introductions, whether intentional or unintentional. In this work, 100 high-priority plant pathogens were identified and literature on each of them was searched for key information to be curated for inclusion in a database on pathogens of importance in agricultural systems. The plant pathogen information and keywords contained in the AgDB were inserted directly into the MRS Central Web format, such that Webbased queries can be executed on demand and literature lists can be tailored to a user's query parameters. The aim of the MRS Central AgDB aligns with the overall scope of the original MRS database to eliminate data ambiguities for threatening pathogens, thus providing law enforcement, forensic, and intelligence communities with an additional tool to counteract agricultural emergencies.

\section{Acknowledgments}

This work was funded under contract GS23F8006H from the Federal Bureau of Investigation. We thank D. Huber, Ph.D., Ohio State University (alumnus); K. Smith, Ph.D., United States Department of Agriculture (USDA) Office of Pest Management Policy and USDA National Plant Disease Recovery System; A. Vidaver, Ph.D., University of Nebraska and member of the National Science Advisory Board for Biosecurity; D. Luster, Ph.D., USDA Agricultural Research Service and Chair of the American Phytopathological Society (APS) Emerging Diseases \& Pathogens Committee; U. Melcher, Ph.D. and F. O. Corona, Ph.D., Oklahoma State University; and members of the APS Microbial Forensics Interest Group and the APS Emerging Diseases \& Pathogens Committee for their valuable input on the selection of the plant pathogens; and the Oklahoma Agricultural Experiment Station, project 1929, for their support.

\section{Literature Cited}

1. Brasier, C. M. 2008. The biosecurity threat to the UK and global environment from international trade plants. Plant Pathol. 57:792-808.

2. Breeze, R. 2004. Agroterrorism: Betting far more than the farm. Biosecur. Bioterr. 2:251-264.

3. Burgess, L. 2003. Biosecurity, trade and plant pathology. Australas. Plant Pathol. 32:129-131.

4. Casagrande, R. 2000. Biological terrorism targeted at agriculture: The threat to US national security. Nonprolif. Rev. 92-105

5. Eagling, D. 2009. Soilborne diseases in the context of plant biosecurity. Australas. Plant Pathol. 38:334-337.

6. Ecker, D. J., Sampath R., Willett, P., Wyatt, J. R., Samant, V., Massire, C., Hall, T. A., Hari, K., McNeil, J. A., Buchen-Osmond, C., and Budowle, B. 2005. The Microbial Rosetta Stone Database: A common structure for microbial biosecurity threat agents. J. Forensic Sci. 50:1380-1385.

7. Ecker, D. J., Sampath, R., Willett, P., Wyatt, J. R., Samant, V., Massire, C., Hall, T. A., Hari, K., McNeil, J. A., Buchen-Osmond, C., and Budowle, B. 2005. The Microbial Rosetta Stone Database: A compilation of global and emerging infectious microorganisms and bioterrorist threat agents. BMC Microbiol. 5:19.

8. Fletcher, J., Bender, C., Budowle, B., Cobb, W. T., Gold, S. E., Ishimaru, C.A., Luster, D., Melcher, U., Murch, R., Scherm, H., Seem, R. C., Sherwood, J. L., Sobral, B. W., and Tolin, S. A. 2006. Plant pathogen forensics: capabilities, needs, and recommendations. Microbiol. Mol. Biol. Rev. 70:450-471.

9. Gamliel, A. 2008. High consequence plant pathogens. Pages 25-36 in: Crop Biosecurity: Assuring our Global Food Supply. M. L. Gullino, J. Fletcher, A. Gamliel, and J. P. Stack, eds. Springer Press, New York.

10. Gilpen, J. L., Carabin, H., Regens, J. L., and Burden, R. W. 2009. Agriculture emergencies: A primer for first responders. Biosecur. Bioterr. 7:187198.

11. Gullino, M. L., Fletcher, J., Gamliel, A., and Stack, J. P. 2008. Crop Biosecurity. Assuring our Global Food Supply. Springer Press, New York.

12. Hari, K. L., Goates, A. T., Jain, R., Towers, A., Harpin, V. S., Robertson, J. M., Wilson, M. R., Samant, V. S., Ecker, D. J., McNeil, J. A., and Budowle, B. 2009. The Microbial Rosetta Stone: A database system for tracking infectious microorganisms. Int. J. Legal Med. 123:65-69.

13. Huber, D. M., Hugh-Jones, M. E., Rust, M. K., Sheffield, S. R., Simberloff, D., and Taylor C. R. 2002. Invasive pest species: Impacts on agricultural production, natural resources, and the environment. Counc. Agric. Sci. Technol. 20:1-17.

14. Latxague, E., Sache, I., Pinon, J., Andrivon, D., Barbier, M., and Suffert, F. 2007. A methodology for assessing the risk posed by the deliberate and harmful use of plant pathogens in Europe. EPPO Bull. 37:427-435.

15. Madden, L. V., and Van de Bosch, F. 2002. A population-dynamics approach to assess the threat of plant pathogens as biological weapons against annual crops. BioScience 52:65-74.

16. Madden, L. V., and Wheelis, M. 2003. The threat of plant pathogens as weapons against U.S. crops. Annu. Rev. Phytopathol. 41:155-176.

17. Magarey, R. D., Colunga-Garcia, M., and Fieselmann, D. A. 2009. Plant biosecurity in the United States: Roles, responsibilities and information needs. BioScience 59:875-884.

18. McGregor, R. C. 1973. The Emigrant Pests. U.S. Dep. Agric., Animal and Plant Health Inspection Service, Washington, DC. http://www.hear.org/ articles/McGregor1973/

19. Miller, S. A., Beed, F. D., and Harmon, C. L. 2009. Plant disease diagnostic capabilities and networks. Annu. Rev. Phytopathol. 47:15-38.

20. Park, J., Park, B., Veeraraghavan, N., Jung, K., Lee, Y., Blair, J. E., Geiser, D. M., Isard, S., Mansfield, M. A., Nikolaeva, E., Park, S., Russo, J., Kim, S. H., Greene, M., Ivors, K. L., Balci, Y., Peiman, M., Erwin, D. C., Coffey, M. D., Rossman, A., Grünwald, N. J., Luster, D. G., Schrandt, J., Martin, F. Ribeiro, O. K., Makalowska, I., and Kang, S. Phytophthora database: A forensic database supporting the identification and monitoring of Phytophthora. Plant Dis. 92:966-972.

21. Paterson, R. R. 2006. Fungi and fungal toxins as weapons. Mycol. Res 110:1003-1010.

22. Rodoni, B. 2009. The role of plant biosecurity in preventing and controlling emerging plant virus disease epidemics. Virus Res. 141:150-157.

23. Schaad, N. W., Abrams, J., Madden, L. V., Frederick, R. D., Luster, D. G., Damsteegt, V. D., and Vidaver, A. K. 2006. An assessment model for rating high-threat crop pathogens. Phytopathology 96:616-621.

24. Simberloff, D., and Alexander, M. 1998. Assessing risks to ecological systems from biological introductions. Pages 147-176 in: Handbook of Environmental Risk Assessment and Management. P. Calow, ed. Blackwell Science, Oxford.

25. Stack, J., Cardwell, K., Hammerschmidt, R., Byrne, J., Loria, R., SnoverClift, K., Baldwin, W., Wisler, G., Beck, H., Bostock, R., Thomas, C., and Luke, E. 2006. The National Plant Diagnostic Network. Plant Dis. 90:128136.

26. Strange, R. N., and Scott, P. R. 2005. Plant disease: A threat to global food security. Annu. Rev. Phytopathol. 43:83-116.

27. Suffert, F., Latxague, E., and Sache I. 2009. Plant pathogens as agroterrorist weapons: Assessment of the threat for European agriculture and forestry. Food Sec. 1:221-232.

28. Wheelis, M., Casagrande, R., and Madden, L. V. 2002. Biological attack on agriculture: Low-tech, high impact bioterrorism. BioScience 52:569-576.

29. Young, J. M., Allen, C., Coutinho, T., Denny, T., Elphinstone, J., Fegan, M., Gillings, M., Gottwald, T. R., Graham, J. H., Iacobellis, N. S., Janse, J. D., Jacques, M. A., Lopez, M. M., Morris, C. E., Parkinson, N., Prior, P., Pruvost, O., Rodrigues, N. J., Scortichini, M., Takikawa, Y., and Upper, C. D. 2008. Plant-pathogenic bacteria as biological weapons-real threats? Phytopathology 98:1060-1065. 